\title{
The Principles of Environmental Based Development in International Law and Sustainable Development Goals
}

\author{
Sandy Kurnia Christmas ${ }^{1}$, Aminah ${ }^{2}$ \\ 1 Postgraduate Study, Faculty of Law, Universitas Diponegoro, Indonesia \\ ch.sandykurnia@gmail.com \\ 2 Faculty of Law, Universitas Diponegoro, Indonesia \\ aminahlana@gmail.com
}

\begin{abstract}
Introduction to The Problem: The Sustainable Development Goals or SDGs are development goals in 2030 to carry out environmentally sound development, which explicitly aims to carry out development that is to meet environmental sustainability and is based on human rights. It is also an adaptation of the principles of the Stockholm Declaration 1972.

Purpose/Objective Study: This research is to find the principles of environmentally sound development, both within the principles of international law and the SDGs principles, that are expected in future development policies to be carried out in the perspective of the right to the environment, both the central and regional governments.

Design/Methodology/Approach: In this doctrinal law research, it is examined using the conceptual approach contained in the principles of development and environmental principles contained in the substance of international law.

Findings: In the principles of international law, there are seven principles of sustainable development goals agreed by the international community in the Rio Conference as a guideline in implementing equitable development based on human rights, which also must be guided by the targets of sustainable development within the SDGs.
\end{abstract}

Paper Type: Research Article

Keywords: Environment; Development; International Law; Sustainable Development Goals

\section{Introduction}

Development in the current era of globalization is inseparable from the influence of the environment. Related to the environmental relationship between development, it positively affects the damage to the environment. The emergence of environmental problems, is inseparable from the debate between, both in development and the environment, where development must aim to pay attention to the quality of the environment that is within the boundaries that support other lives. Development in this globalization era is also inseparable from the influence of economic policy in 


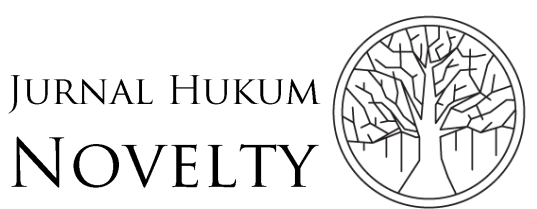

Volume 10, Issue 02, 2019, pp. 101-110

conducting free trade; this becomes a dilemma between overtaking economic interests to pursue development or environmental interests (Ruslin, 2014).

To carry out development, we need to pay attention to environmental aspects, where sustainable development must be supported on an environmental basis. The lousy impact that occurs when carrying out development policies without regard to environmental aspects is the sustainability of the environment in the future (Christie, 2013). Preventive measures also need to be taken to avoid environmental damage. This action is considered essential to preserve the environment and other natural resources (Hutagalung, 2010).

Development programs often have an impact on the occurrence of environmental destruction, where both the government and the community still lack understanding of taking advantage of nature in maintaining its sustainability (Lestari \& Djanggih, 2019). The case that happens, such as intentionally error in making Environment Impact Analysis.

In this case, we need a supported development concept that facilitates environmental planning. Sustainable Development is a development paradigm related to the balance of nature, where it has comprehensible and planned effort in integrating environmental, social and economic aspects into development strategy that supports environmental sustainability for life. The paradigm is in accordance with the four main bases for the development of The Global Cooperation Coalition and also following the definition of Law No. 32 of 2009 on Environment Protection and Conservation (Rosana, 2018).

In this research, the interaction between development and the environment is linked to the principles of the right to the environment, both within the principles and objects of the Sustainable Development Goals of 2030 that adopted from the UN Conference on Sustainable Development (Rio+20 Conference), New Delhi Declaration. Therefore, to understand SDGs, two problem topics can be formulated, namely: 1) How is the principle of sustainable development in International Law and 2) How is the principle of the insightful environment in the Sustainable Development Goals?

\section{Methodology}

This research used the qualitative method, and it is a doctrinal legal approach that examines the rules or norms in law and through the Conceptual Approach and Case Study Approach (Soekanto, S. \& Mamudji, 2014). In this research the primary legal materials are in the form of international agreements on the environment such as the ILA New Delhi Declaration of Principles of International Law Relating to Sustainable Development; Conference of Rio+20 2012 (The UN Conference on Sustainable Development); Stockholm Conference 1972 (Declaration of the UN Conference on the Human Environment); as well as secondary legal material that contains journals, papers and literature. 
P-ISSN: $1412-6834$

E-ISSN: 2550-0090

\section{Results and Discussion}

\section{Principles of the Sustainable Development in International Law}

Sustainable Development, in essence, is an understanding of the interaction between nature and society, which is carried out the sustainability related to the human basic human needs. It means that there must be commitment from the community and the government in protecting the environment and keeping it away from pollution and environmental damage (Desfandi, 2015). Problems with the environment have always been a significant cause of disasters so that environmental management must be well organized.

Environmental law stipulates provisions and norms that aim to regulate human actions to protect the environment from deterioration, as well as to ensure its sustainability so that future generations could take advantage of a well-preserved environment. The right to have a well and healthy environment is a form of human rights as regulated in The 1945 Constitution of the State of the Republic of Indonesia. The environment is vital in the human life cycle and is an essential asset to be managed and protected for its function (Permadi, 2016).

Environmental law always appears along with the emergence of environmental problems. It then brought to various environmental settings such as the Smelter Trail Arbitration, Lac Lanoux Arbitration, and Case Corfu-Channel. The reason for this usually based on the development of residential, industrial or plantation areas, which sometimes neglect environmental sustainability and are only concerned with personal profit factors. It makes the issue of the environment unfinished because it is always in a clash with gratuitous development.

Environmental Issues have been discussed since the 1990s. Based on data from the United Nations Environment Program (UNEP) in 1991, it was more than 6,1 billion hectares of dry land that $70 \%$ had become deserts due to drought (World Meteorological Organization/UN Environment Programme, 1992). Another report from the Food and Agriculture Organization (FAO) in 1995 stated that 56,3 million hectares of tropical forest diminished, and 11,3 million hectares of forest are damaged (Pandey, 1995). The data shows the importance of balancing the ongoing development alongside with preserving the environment as a basis of development goals. The issues also influence the substance of other international laws in the trade sector, where the WTO in 1994 issued an environmental regulation, namely "The Ministerial Decision on Trade and Environment," which has three program priorities, which are world trade policy, environmental policy, and sustainable development.

The beginning review on sustainable development is a concept that born from human needs to develop their living life and also the awareness of environmental preservation. Both human needs and the awareness then encourage United Nations 


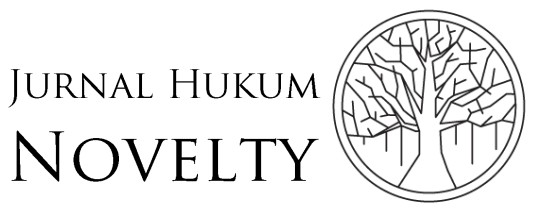

Volume 10, Issue 02, 2019, pp. 101-110
P-ISSN: $1412-6834$

E-ISSN: 2550-0090

to establish the World Commission on Environment and Development (WCED) or often referred to as the Brundtland Commission, to study development and environmental issues (Wibisana, 2013).

Regarding the Environment in international legal arrangements, the discussion in Article 1 of the International Covenant on Civil and Political Rights (ICCPR) and the International Covenant on Economic Social and Cultural Rights (ICESCR) which has the same discussion about the environment, are:

"Article 1: ICCPR \& ICESCR

(a) All peoples have the right to self-determination. By virtue of that right they freely determine their political status and freely pursue their economic, social and cultural development.

(b) All peoples may, for their own ends, freely dispose of their natural wealth and resources without prejudice to any obligations arising out of international economic co-operation, based upon the principle of mutual benefit, and international law. In no case may a people be deprived of its own means of subsistence."

While Principles of International Law Relating to Sustainable Development and in the Rio+20 Conference stated that sustainable development consists of several legal principles, namely:

1. The Principle of Sustainable Use (the state's obligation to ensure the sustainable use of natural resources);

2. The Principles of Intra and Intergenerational Justice (the principle of equality and poverty alleviation);

3. The Principle of Shared Responsibility but With Different Burdens;

4. The Principle of the Precautionary Approach to Human Health, Natural Resources, and Ecosystems;

5. The Principle of Public Participation and Access to Information and Justice;

6. The Principle of Good Governance; and

7. The Principle of Integration (relation to human rights and social, economic, and environmental objectives).

Therefore, in achieving sustainable development goals that are environmentally friendly, there are strategies we must set:

1. Paying attention to aspects of intergenerational development (intergeneration equity) as well as emphasizing the level of exploitation of natural resources;

2. Safeguarding strategies to prevent ecosystem disturbance in order to increase the guarantee of good quality natural and environmental resources;

3. In pursuing the interests of economic growth, it needs awareness for sustainable use and management of natural resources between generations;

4. Paying attention to the welfare of the community, both now and in the future (intertemporal). 
5. Development must have long-term benefits in managing natural resources and the environment; and

6. Preserve the quality of human life in harmony with the environment.

Although there are institutions such as the WTO which regulate the environment in Article XX paragraph (b) and (g) and enforce environmental law as a function of environmental sustainability, the implementation of this regulation is not yet fully achieved. It is because there are still many countries that have no attention to environmental standards.

\section{Development Principles in Sustainable Development Goals/SDGs}

Sustainable Development Goals (SDGs) are part of the continuation of the Millennium Development Goals (MDGs), which uncompleted in 2015. In principle, the implementation of SDGs is to integrate development aspects in the social, economic, and environmental fields. This agenda is fundamental as its commitment until 2030, which is inclusive-oriented action to realize development for human and earth welfare.

Sustainable Development Goals are new development agreements for achieving sustainable development based on human rights and equality to encourage social, economic, and environmental development. SDGs have universal, integrated and inclusive principles to ensure that no one is missed in development.

The SDGs have 17 Sustainable Development goals with 169 target points that must be carried out for conservation goals and sustainable principles. SDGs can be said as a human rights-based development goal, where the connotation of human rights is not only human but nature and surroundings that are part of promoting growth and development.

Right-based development on the environment is, in principle, a development that pays attention to environmental aspects and natural resources or also known in the Environmental Development In the perspective of human rights as the fulfillment of the right to economic and management of natural resources (Utomo, 2014). It is guaranteed in the Universal Declaration of Human Rights in Article 22, which states that:

"Every person as a member of society has the right to social security and the realization of economic, social and cultural rights which are indispensable for the dignity and development of his personality freely, through national efforts and international cooperation, and in accordance with the arrangements and resources available in each country."

An important SDGs indicator that discusses the environment is avoiding and reducing environmental degradation. It is like reducing the negative impact on the changes in the structure of land and forest areas that need to be restored. The International Organization's contribution to nature conservation by the International Union for 


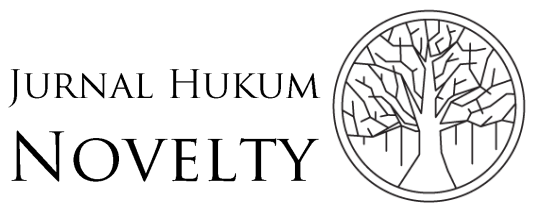

Volume 10, Issue 02, 2019, pp. 101-110
P-ISSN: $1412-6834$

E-ISSN: 2550-0090

Conservation of Nature (IUCN) defines nature conservation as a geographical space, dedicated and managed through law or other effective means, to achieve the longterm conservation of nature associated with ecosystem services and cultural values. The central management in conservation includes restoration and sustainable use.

The concept of rights-based development on the environment has the same concept in the sustainable development effort, which implies processing resources to improve the welfare of the present without reducing the ability of future generations to process resources to improve their welfare (Pratiwi, 2018). Sustainable development is a wise choice in efforts to improve the quality of life that supports the carrying capacity of the earth. Based on the International Conference on Public Health these goals can be achieved through four elements, namely: Economic growth and equity, social development, Conservation of natural resources (environmental protection), and Good governance. These four elements support each other and sustainable development goals (ICPH, 2016).

The SDGs aims explicitly to reduce poverty and hunger, existing imbalances within and between countries, improve water and energy management, and take urgent steps to tackle climate change. The SDGs focus on strategic efforts to increase economic growth, as well as to meet various social needs (education, health, social protection, employment opportunities), and policy steps to address climate change and environmental protection.

In the SDGs, there are important things to realize the interests of rights-based development on the environment, especially in Indonesia, namely:

1. Sustainable development goals within the SDGs adhere to the latest sustainability models, where these goals are not separate objectives between economic, social, and cultural aspects. It can be concluded that economic aspects are subject to social interests in environmental sustainability in order to realize the sustainable development of 2016-2030.

2. Environmental aspects have six essential elements in their conceptual forms, namely: planet, people, dignity, prosperity, justice, and partnership.

3. The things outlined in the SDGs objectives are 17 Goals and 169 Targets, where environmental aspects are outlined in Goal 6 regarding water and sanitation (water resources); Goal 7 regarding energy; Objective 9 regarding infrastructure, industrialization and innovation; Goal 11 regarding cities and settlements; Goal 12 regarding production and consumption; Goal 13 regarding climate change; Goal 14 concerning the sea; and Destination 15 regarding land.

4. The goals and targets in the SDGs have been reviewed by a group of scientists from the International Council for Science (ICSU) and the International Social Science Council (ISSC), where the results are contained in the document Review of Targets for Sustainable Goals: The Science Perspective. 
Concerning environmental sustainability, not all targets set in the Goals of Sustainable Development can run according to the indicators of these targets. It can be seen from the International Training Center data on sustainable development goals where there are objectives that are aligned with environmental issues (International Training Centre, 2018):

1. Goals 11: Making Cities and Settlements Inclusive, Safe, Resilient and Sustainable

a. Strengthen efforts to protect and preserve world cultural heritage and natural heritage (Goal 11.4)

b. Reducing adverse urban environmental impacts, including paying particular attention to air quality and municipal handling waste (Goal 11.6)

c. Providing public spaces and open spaces that are safe, inclusive and easily accessible, especially for women and children, seniors and people with disabilities (Goal 11.7)

2. Goals 12: Guaranteeing Sustainable Production and Consumption Patterns

a. Achieve sustainable management and efficient use of natural resources (Goal 12.2)

b. Reducing waste production through prevention, reduction, recycling, and reuse. (Goal 12.5)

c. Ensure that people everywhere have relevant information and awareness of sustainable development with lifestyles that are in harmony with nature. (Goal 12.8)

3. Goals 13: Take Quick Action to address Climate Change and its Impacts.

a. Strengthening resilience and adaptation capacity to climate-related hazards and natural disasters in all countries (Goal 13.1)

b. Integrate climate change anticipation measures into national policies, strategies, and planning (Goal 13.2)

c. Improve education, foster awareness, and human capacity and related institutions in reducing impacts and early warning related to climate change. (Goal 13.2)

4. Goals 14: Preserve and Make Sustainable Use of Ocean and Ocean Resources for Sustainable Development

a. Prevent and significantly reduce all types of marine pollution, especially from land-based activities, including marine waste and nutrient pollution. (Goal 14.1)

b. Manage and protect marine and coastal ecosystems in a sustainable manner to avoid significant adverse impacts, including by strengthening their resilience, and carrying out restoration to realize healthy and productive oceans (Goal 14.2)

c. Preserve at least 10 percent of the coastal and marine areas, consistent with national and international law, and based on the best scientific information. (Goal 14.5) 


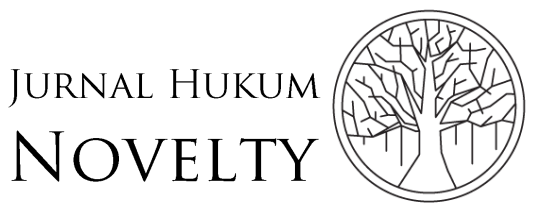

Volume 10, Issue 02, 2019, pp. 101-110
P-ISSN: $1412-6834$

E-ISSN: 2550-0090

d. Enhance economic benefits for developing small islands and less developed countries from the sustainable use of marine resources, including through sustainable fisheries management, aquaculture, and tourism (Goal 14.7)

e. Enhancing the preservation and sustainable use of oceans and their resources by applying international law as reflected in the United Nations Convention on Maritime Law in providing a legal framework for the preservation and sustainable use of marine resources. (Goal 14.C)

5. Goals 15: Protecting, Restoring and Enhancing the Sustainable Use of Mainland Ecosystems, Managing Forests in a Sustainable Way, Stopping Use, Restoring Land Degradation, and Stopping Biodiversity Loss

a. Ensure the preservation of restoration and sustainable use of terrestrial and terrestrial ecosystems and their environmental services, especially forest ecosystems, wetlands, mountains, and drylands, in line with obligations under international agreements. (Goal 15.1)

b. Improve implementation of sustainable management of all types of forests, stop deforestation, restore degraded forests and significantly increase afforestation and reforestation globally (Goal 15.2)

c. Stop desertification, restore land affected by desertification, drought, and floods, and strive to achieve a world free of degraded land. (Goal 15.3)

d. Ensuring the preservation of mountain ecosystems, including their biodiversity, to enhance their capacity to provide benefits that are essential for sustainable development (Goal 15.4)

e. Take rapid and significant actions to reduce the degradation of natural habitats, stop biodiversity loss, protect species and prevent the disappearance of endangered species (Goal 15.5)

Management of the environment, including prevention, mitigation of damage, and pollution and restoration of the quality of the environment, has demanded the development of various policies and programs that support environmental management in a development program (Herlina, 2015). In this case, there should be no intervention from the policies of the authorities and political elites to destroy the environment. The implementation of issued-policies must be in favor of the environment, if not in favor of environmental functions and the general public, exploitation of natural resources will only meet the needs of the economic market, regardless of environmental damage, this will adversely affect the quality of human life (Drakel, 2010).

\section{Conclusion}

The presence of the concept in the objectives of the SDGs is a concept developed by the countries in the Rio +20 Conference, which is a joint agreement between countries to realize environmentally-friendly development. The objective of 11 SDGs in urban and community planning was agreed to making cities and settlements inclusive, safe, resilient, and sustainable, which by 2030 has to achieve efficient management of natural resources. The purpose of the SDGs concept is to implement policy rules, both 
at the central and regional levels. This effort in the SDGs is also an interpretation and adaptation of international law in the Declaration of the United Nations Conference on the Human Environment (Stockholm Declaration 1972). The principles declared in Stockholm became a relationship of agreements which from the beginning were developed into SDGs that support not only developing the environment but supporting the fulfillment of human rights in development.

\section{References}

Christie, Y. A. (2013). Dampak kerusakan lingkungan akibat aktivitas pembangunan perumahan (Studi kasus perumahan Palaran City oleh PT. Kusuma Hady Property). Jurnal Beraja Niti, 2(11), 1-21. Retrieved from http://id.portalgaruda.org/?ref=browse\&mod=viewarticle\&article=143857

Desfandi, M. (2015). Mewujudkan masyarakat berkarakter peduli lingkungan melalui program Adiwiyata. Sosio Didatika: Social Sciece Education Journal, 2(1), 31-37. https://doi.org/10.15408 /sd.v2i1.1661.

Drakel, A. (2010). Kebijakan pengelolaan lingkungan hidup berbasis ekonomi sumberdaya di Provinsi Maluku Utara. Jurnal Ilmiah Agribisnis Dan Perikanan, 3(1), 90-100. https://doi.org/10.29239/j.agrikan.3.1.90-100

Herlina, N. (2015). Permasalahan lingkungan hidup dan penegakan hukum lingkungan di Indonesia. Jurnal Ilmiah Galuh Justisi, 3(2), 1-15. https://doi.org/10.25157/jigj.v3i2.93.

Hutagalung, S. R. A. (2010). Pengelolaan lingkungan untuk keberlanjutan pengembangan ekonomi lokal di sentra industri penyamaan kulit Garut. Jurnal Perencanaan Wilayah dan Kota, 21(1), 1-17. Retrieved from http://journals.itb.ac.id/index.php/jpwk/article/view/4147/2230

ICPH. (2016). Sustainable development goals. Retrieved from International Conference On Public Health website: http://theicph.com/id_ID/id_ID/icph/sustainable-development-goals/

International Training Centre. (2018). Tujuan pembangunan berkelanjutan: Refernsi manual serikat pekerja untuk agenda pembangunan berkelanjutan 2030. Jakarta: Organisasi Perburuhan Internasional.

Lestari, S. E., \& Djanggih, H. (2019). Urgensi hukum perizinan dan penegakannya sebagai sarana pencegahan pencemaran lingkungan hidup. Masalah-Masalah Hukum, 48(2), 147-163. https://doi.org/10.14710/mmh.48.2.2019.147-163.

Pandey, D. (1995). Forest resources assessment 1990 tropical forest plantation resources. Retrieved June 5, 2019, from Food and Agricultural Organization of the UN website: http://www.fao.org/3/v8330e/v8330e00.htm

Permadi, I. M. A. (2016). Kewenangan Badan Lingkungan Hidup dalam pemberian sanksi administratif terhadap pelanggaran pencemaran lingkungan. Jurnal Magister Hukum Udayana, 5(4), 650-660. https://doi.org/10.24843/JMHU.2016.v05.i04.p02

Pratiwi, P. H. (2018). Kebijakan nasional terhadap pembangunan berwawasan lingkungan. Dimensia, 2(1), 101-112. Retrieved from 
https://journal.uny.ac.id/index.php/dimensia/article/view/3400

Rosana, M. (2018). Kebijakan pembangunan berkelanjutan yang berwawasan lingkungan di Indonesia. Jurnal Kelola, 1(1), 148-163. Retrieved from http://journal.uinsgd.ac.id/index.php/kelola/article/view/4128

Ruslin, I. T. (2014). Lingkungan hidup dan liberalisasi perdagangan global mendamaikan yang tidak dapat damai. Jurnal Politik Profetik, 3(1), 1-14. Retrieved from http://103.55.216.55/index.php/jpp/article/view/815

Soekanto, S., \& Mamudji, S. (2014). Penelitian hukum: Suatu tinjauan singkat. Jakarta: PT. Raja Grafindo.

Utomo, S. (2014). Pengaruh pembangunan di era globalisasi terhadap pemenuhan hak asasi manusia atas lingkungan hidup yang baik dan sehat. Jurnal Pembaharuan Hukum, 1(3), 258-266. Retrieved from http://jurnal.unissula.ac.id/index.php/PH/article/view/1487

Wibisana, A. G. (2013). Pembangunan berkelanjutan: Status hukum dan pemaknaannya. Jurnal Hukum \& Pembangunan, 4(1), 54-90. https://doi.org/10.21143/jhp.vol 43.no1.1503

World Meteorological Organization/UN Environtment Programme. (1992). Climate change: The IPCC 1990 and 1992 assessments. Retrieved May 5, 2019, from UN Environtment Programme website: https://www.unenvironment.org/resources/report/climate-change-ipcc1990-and-1992-assessments 